\title{
Morphogenetic effect of glycerol on tissue cultures of the red seaweed Grateloupia doryphora
}

\author{
R.R. Robaina, P. Garcia, G. Garcia-Reina \& A. Luque \\ Departamento de Biologia, Facultad de Ciencias del Mar, Universidad de Las Palmas G.C., Box 550, Las \\ Palmas G.C., Canary Islands. Spain
}

Received 20 February 1990; accepted 24 February 1990

Key words: carbon-source, glycerol, Grateloupia doryphora, morphogenesis, osmolality, solidity, tissue culture

\begin{abstract}
Explants of Grateloupia doryphora were cultivated in Provasoli Enriched Seawater culture medium (PES) supplemented with glycerol $\left(0.1 .0 .3,0.5\right.$ or $\left.0.8 \mathrm{~mol} \mathrm{l}^{-1}\right)$ or carbohydrates $\left(0.1\right.$ or $0.3 \mathrm{~mol}^{-1}$ mannose. glucose and galactose) and agar $\left(3,8,15 \mathrm{~g} \mathrm{l}^{-1}\right)$. The osmolality of the medium was adjusted by dilution of the seawater ( 70 or $100 \%, \mathrm{v}$ ). The increase in fresh weight of explants cultivated in liquid medium with glycerol $\left(0.3 \mathrm{~mol}^{-1}\right)$ and without glycerol was compared. All experiments were carried out in the light, except for one assay in which the explants were cultivated in the dark. Glycerol was an effective carbon source for the vegetative propagation of $G$. doryphora in solid and liquid media. Mannose, glucose and galactose all had no effect on growth or morphogenesis of the explants. In solid media the main effect of glycerol was as a morphogenetic inductor, with PES70 (70\% seawater) +0.1 or $0.3 \mathrm{~mol} 1^{-1}$ glycerol +3 or $8 \mathrm{~g} \mathrm{l}^{-1}$ agar the best formulation. An increase in the concentration of agar in glycerolcontaining medium reduced the morphogenetic capacity of the explants, which developed into compact cell masses. The effects of glycerol were observed only in explants cultivated under light.
\end{abstract}

Abbreviations: PES. Provasoli Enriched 100\% Seawater; PES70, Provasoli-Enriched 70\% (v v) seawater in distilled water.

\section{Introduction}

Carbon sources effective for culture of seaweeds and tissue cultures seem to be those that are accumulated by seaweed cells (Saga et al., 1982; Fries, 1984). Red seaweeds accumulate glycerol in the form of isofloridoside, floridoside (isomeric compounds of galactosyl-glycerol) or digeneaside (mannosyl-glycerol (Lobban et al., 1985), all of which appear to be involved in cellular osmo- adaptation (Kauss, 1967; Reed et al.. 1980; Reed, 1985). Fries (1973) reported that glycerol is an effective carbon source for the vegetative propagation of several red seaweeds.

Robaina et al. (1990) reported a strong effect of high osmolality and solidity (agar concentration) on bud regeneration and callus formation in Grateloupia doryphora. They pointed out that the addition of glycerol to the culture medium modifies the response of the expants by the carbon 
source effect of glycerol and also by the modification of the osmolality.

The aim of the present work was to study the effects of glycerol and other carbon sources on tissue cultures of $G$. doryphora with controled osmolality and solidity of the culture medium.

\section{Material and methods}

Grateloupia doryphora (Montagne) Howe was collected in Gran Canaria (Canary Islands). Two h after collection, disc fragments $13 \mathrm{~mm}$ diameter) were excised from the middle-lower thallus. Disc fragments were rinsed for $5 \mathrm{~min}$ in distilled water and mechanically cleaned with brushes and sonication ( 3 times, $1.5 \mathrm{~min}$ each). The explants were then immersed in Betadine $\left(5^{\circ}, \mathrm{v} / \mathrm{v}\right.$ of Betadine, $10 \%$ polyvinylpyrrolidone-iodine complex commercial solution. Sarget Lab. Barcelona. Spain) for $7 \mathrm{~min}$. Sterilization was continued by incubation for 5 days in $10 \mathrm{ml}$ autoclaved seawater with penicillin (300 $\mathrm{mg} \mathrm{l}^{-1}$ ) (Sigma), ampicillin (30 $\left.\mathrm{mg} \mathrm{l}^{-1}\right)$ (Sigma), nystatin ( $\left.25 \mathrm{mg} \mathrm{l}^{-1}\right)$ (Sigma) and germanium dioxide $\left(5 \mathrm{mg} \mathrm{l}^{-1}\right)$ (Aldrich). The fragments were tested for sterility by cultivation for 10 days in Provasoli Enriched Seawater (PES, Provasoli 1968) supplemented with glucose $(0.5 \mathrm{~g}$ $\left.1^{-1}\right)$, sucrose $\left(1 \mathrm{~g} \mathrm{I}^{-1}\right)$, casein bydrolysate $(0.5 \mathrm{~g}$ $\left.1^{-1}\right)$ and lactose broth $\left(1 \mathrm{~g} \mathrm{I}^{-1}\right.$, Difco). Disc fragments apparently free of contaminants (under stereomicroscope) were transferred to agarized PES medium. After 30 days, semicircular-shaped explants (ca $1 \mathrm{~mm}$ long) were excised from the disc fragments.

Explants were cultivated in Petri dishes with $20 \mathrm{ml}$ of culture media. Cultures were placed at $22 \pm 2{ }^{\circ} \mathrm{C}$ in a growth chamber adjusted to a day length of $18 \mathrm{~h}$ and $27 \mu \mathrm{mol} \mathrm{m} \mathrm{m}^{-2} \mathrm{~s}^{-1}$ (Sylvania Grolux) at the level of the Petri dishes.

The culture medium for semicircular explants was an enriched seawater medium based on PES. which was supplemented with $0.0,0.3,0.5$ and $0.8 \mathrm{~mol} \mathrm{l}^{-1}$ glycerol (Merck). The seawater was diluted and the appropiate amount of glycerol was added to reach the osmolalities shown in Table 1. The osmolality was checked in a Autostat TM osmometer (Daiichi Kogaku Co. Ltd, Tokyo. Japan). All experiments were carried out with solid culture medium ( $8 \mathrm{~g}^{-1}$ agar), but the fresh weight increased of semicircular explants cultivated in liquid PES70 $+0.3 \mathrm{~mol}^{-1}$ glycerol was also monitored during 45 days (reculture every 15 days). A control assay was made in liquid PES.

After 20 days, explants were transferred from solid culture media with high concentration of glycerol - high osmolality $\left(1.5 \mathrm{Os} \mathrm{kg}^{-1}\right)$ (Table 1) to solid medium with $0.3 \mathrm{moll}^{-1}$ glycerol (1.0 Os $\mathrm{kg}^{-1}$ ).

The effects of glycerol, mannose, glucose and galactose were compared by cutting and cultivating the buds (ca $0.5 \mathrm{~mm}$ long) that sprout at the border of initially cultivated disc fragments. The buds (explants; 15 per treatment) were cultivated for 30 days in PES70 +0.1 or $0.3 \mathrm{~mol} \mathrm{l}^{-1}$ of the carbon sources $+8 \mathrm{~g} \mathrm{l}^{-1}$ agar (Table 1 ).

Table 1. Concentration of seawater. glycerol and carbohydrates (mannose, glucose or galactose) in the different culture media.

\begin{tabular}{lllll}
\hline $\begin{array}{l}\text { Culture } \\
\text { medium }\end{array}$ & $\begin{array}{l}\text { Seawater } \\
(\%, v / v)\end{array}$ & $\begin{array}{l}\text { Osmolality } \\
\left(\mathrm{Os} \mathrm{Kg}^{-1}\right)\end{array}$ & $\begin{array}{l}\text { Glycerol } \\
\left(\mathrm{mol} \mathrm{I}^{-1}\right)\end{array}$ & $\begin{array}{l}\text { Carbohydrates } \\
\left(\mathrm{mol} \mathrm{l}^{-1}\right)\end{array}$ \\
\hline PES70 & 70 & 0.7 & 0 & 0 \\
& & 0.8 & 0.1 & 0 \\
& & 1.0 & 0.3 & 0.1 \\
PES & & 1.5 & 0 & 0.3 \\
& 100 & 1.5 & 0.8 & 0 \\
\hline
\end{tabular}


Agar concentation experiments were carried out varying the usual concentration $\left(8 \mathrm{~g}^{-1}\right)$ of the PES70 $+0.3 \mathrm{moll}^{-1}$ glycerol to 3 or $15 \mathrm{~g} \mathrm{l}^{-1}$ agar. Semicircular explants were used in these experiments (15 explants in each medium).

An experiment was made to see the effects of light on growth. Fifteen semicircular explants were cultivated in darkness in PES70 $+0.3 \mathrm{~mol}$ $1^{-1}$ glycerol and $8 \mathrm{~g} \mathrm{l}^{-1}$ agar.

The morphogenetic response of the explants was quantified by 'number of buds/number of cultivated explants' and/or 'number of buds/ number of morphogenetic explants' (GarciaReina \& Luque, 1988). The increase in length of the bud explants was used to quantify experiments with this material.

\section{Results}

\section{Effects of glycerol on growth and regeneration of the explants}

Glycerol had a positive effect on explant growth and morphogenetic capability. Within 45 days of cultivation, liquid PES70+0.3 $\mathrm{mol} \mathrm{l}^{-1}$ glycerol increased fresh weight of explants by more than $400 \%$ over PES (Fig. 1). In solid PES $70+0.3 \mathrm{~mol}^{-1}$ glycerol ( 3 or $8 \mathrm{~g} \mathrm{l}^{-1}$ agar), the semicircular explants turned from reddish to

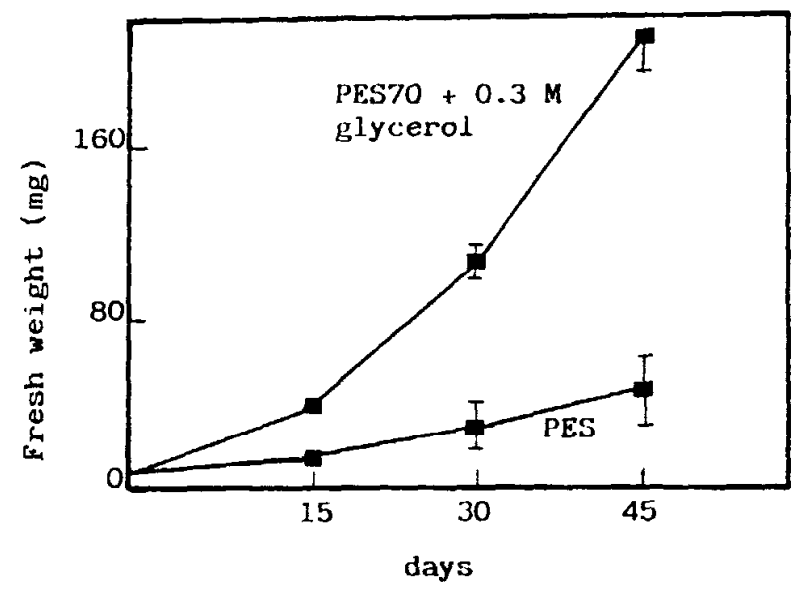

Fig. 1. Variation of the fresh weight of explants cultivated in liquid PES70 $+0.3 \mathrm{moll}^{-1}$ glycerol and liquid PES (average fresh weight from three replicates with 15 explants in each. Vertical bars $= \pm$ SD). orange and became rounded and bigger than those in the other culture media. After 25 days, the growth of the explants made it necessary to subculture them to avoid desiccation and death.

The index 'number of buds/number of cultivated explants' decreased from culture media without glycerol (PES70) or with $0.3 \mathrm{~mol} \mathrm{1}^{-1}$ glycerol $\left(0.7\right.$ and $1.0 \mathrm{Os} \mathrm{kg}^{-1}$ respectively) to media with 0.5 or $0.8 \mathrm{~mol} \mathrm{l}^{-1}$ glycerol $(1.5 \mathrm{Os}$ $\mathrm{kg}^{-1}$ ) (Table 2).

Explants cultivated on media with PES $+0.5 \mathrm{~mol} 1^{-1}$ and PES70 $+0.8 \mathrm{~mol}^{-1}$ glycerol were transferred to the $0.3 \mathrm{~mol} \mathrm{I}^{-1}$ glycerol $+8 \mathrm{~g} \mathrm{l}^{-1}$ agar medium. After 20 days, $70 \%$ of the explants recultivated from PES $+0.5 \mathrm{~mol} \mathrm{l}^{-1}$ glycerol, and $90 \%$ of those recultivated from PES $+0.8 \mathrm{~mol} 1^{-1}$ glycerol showed bud regeneration. Explants recultivated from PES $70+0.5 \mathrm{~mol} 1^{-1}$ glycerol showed higher value of the index "number of buds/number of morphogenetic explants' than explants coming from PES only (Table 3 ). Explants coming from PES70 $+0.8 \mathrm{~mol}^{-1}$ glycerol showed higher values of both "number of buds/number of cultivated explants' and 'number of buds number of morphogenetic explants' than those coming from PES only (Table 3 ).

After 30 days, the bud explants were larger and regenerated new buds, which sprouted around them. The bud explants cultivated in PES70 and PES showed a significantly higher longitudinal growth than hose cultivated in PES70 $+0.3 \mathrm{~mol}$

Table 2. Values of the index number of buds number of cultivated explants' $(B / C)$ observed in semicircular explants cultivated in different concentrations of glycerol and agar. $(n=15)$.

\begin{tabular}{llcr}
\hline $\begin{array}{l}\text { Osmolality } \\
\left(\mathrm{Os} \mathrm{kg}^{-1}\right)\end{array}$ & $\begin{array}{l}\text { Glycerol } \\
\left(\mathrm{mol} \mathrm{l}^{-1}\right)\end{array}$ & $\begin{array}{l}\text { Agar } \\
\left(\mathrm{g} \mathrm{l}^{-1}\right)\end{array}$ & $\begin{array}{l}\mathrm{B} / \mathrm{C} \\
\text { index }\end{array}$ \\
\hline 0.7 & 0.0 & 8 & 7.1 \\
1.0 & 0.0 & 8 & 7.2 \\
& 0.3 & 3 & 18.3 \\
& 0.3 & 8 & 16.1 \\
1.5 & 0.3 & 15 & 6.2 \\
& 0.5 & 8 & 1.5 \\
& 0.8 & 8 & 2.6 \\
\hline
\end{tabular}


Table 3. Values of the indices 'number of buds number of cultivated explants' $(\mathrm{B} / \mathrm{C})$ and 'number of buds number of morphogenetic explants (B/M) 20 days ater transter from

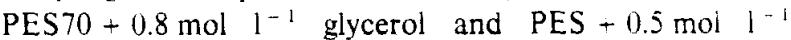
glycerol to PES70 $+0.3 \mathrm{~mol} \mathrm{l}^{-1}$ glycerol (agar $=8 \mathrm{~g} \mathrm{l}^{-1}$ : $n=15$ semicircular explants).

\begin{tabular}{|c|c|c|}
\hline Transfer from & $\begin{array}{l}\text { B C } \\
\text { index }\end{array}$ & $\begin{array}{l}\text { B M } \\
\text { index }\end{array}$ \\
\hline \multicolumn{3}{|l|}{ PES to PES70 $+0.3 \mathrm{~mol} \mathrm{l}^{-1}$} \\
\hline Glycerol (control) & 16.2 & 17.3 \\
\hline \multicolumn{3}{|l|}{ PES $+0.5 \mathrm{~mol} \mathrm{l}^{-1}$ glycerol } \\
\hline to PES70 $+0.3 \mathrm{~mol}^{-1}$ glycerol & 17.4 & 61 \\
\hline \multicolumn{3}{|l|}{$\operatorname{PES} 70+0.8 \mathrm{~mol} \mathrm{l}^{-1}$ glycerol } \\
\hline to PES70 $+0.3 \mathrm{~mol} \mathrm{1}^{-1}$ glycerol & 江 & 87 \\
\hline
\end{tabular}

$I^{-1}$ glycerol (Table 4). Bud explants cultivated in 0.1 and $0.3 \mathrm{~mol}^{-1}$ turned orange, as observed for semicircular explants, and showed the highest morphogenetic response (Table 5). Mannose. glycose and galactose did not affect pigmentation or morphogenesis; no differences were observed among explants cultivated in PES70 or PES and those cultivated in media supplemneted with carbohydrates (Table 5).

\section{Effects of agar concentration}

The 'number of buds/number of cultivated explants' was negatively correlated with the agar concentration (Table 2). The explants cultivated on media with $3 \mathrm{gl}^{-1}$ agar showed bud formation on the border, and the initial explant morphology was maintained. Ten $\%$ of the explants cultivated on media with $8 \mathrm{~g} \mathrm{1}^{-1}$ agar did not regenerate buds: their initial morphology was lost and they developed into compact cell masses larger than

Table 4. Increase in length (average $=\mathrm{SD}$ ) of buds cultivated in solid media ( $8 \mathrm{gl}^{-1}$ agar) with and without glycerol, osmolality $1.0 \mathrm{Os} \mathrm{kg}^{-1}(* *, 0.05>P>0.01, n=15)$.

\begin{tabular}{lc}
\hline Culture medium & $\begin{array}{l}\text { Length } \\
\text { increase }(\mathrm{mm})\end{array}$ \\
\hline PES $70+0.3 \mathrm{~mol}^{-1}$ glycerol & $6.5 \pm 2.2$ \\
PES & $21.7 \pm 6.0\left({ }^{* *}\right)$ \\
\hline
\end{tabular}

Table 5. Values of the index number of buds number of cultivated explants' observed in buds after 30 days of culture in media with and without carbon source. Agar $8 \mathrm{~g} \mathrm{l}^{-1}$ in all media $(n=15)$.

\begin{tabular}{llll}
\hline $\begin{array}{l}\text { Culture } \\
\text { medium }\end{array}$ & $\begin{array}{l}\text { Carbon } \\
\text { source }\end{array}$ & $\begin{array}{l}\text { Concentra. } \\
\left(\text { mol }{ }^{-1}\right)\end{array}$ & $\begin{array}{l}\mathrm{B} / \mathrm{C} \\
\text { index }\end{array}$ \\
\hline PES & - & 0 & 2.8 \\
PES70 & - & 0 & 2.6 \\
PES70 & glycerol & 0.1 & 9.8 \\
& & 0.3 & 7.6 \\
PES70 & mannose & 0.1 & 1.7 \\
& & 0.3 & 1.1 \\
PES70 & glucose & 0.1 & 4.4 \\
& & 0.3 & 2.4 \\
PES70 & galactose & 0.1 & 1.5 \\
& & 0.3 & 2.1 \\
\hline
\end{tabular}

the explants cultivated on media without glycerol. When the agar concentration was increased to $15 \mathrm{~g} \mathrm{l}^{-1}, 47 \%$ of the cultivated explants showed a disorganized pattern of growth (Fig. 2a). Filamentous callus-like masses sprouted from the explants cultivated on 8 and $15 \mathrm{~g} \mathrm{l}^{-1}$ agar.

\section{Effects of darkness}

Explants cultivated in PES70 $+0.3 \mathrm{~mol} \mathrm{I}^{-1}$ glycerol $\left(8 \mathrm{~g} \mathrm{l}^{-1}\right.$ agar) in darkness did not show growth or regeneration.

\section{Discussion}

Bud regeneration in Grateloupia dorvphora is observed only when the osmolality of the culture medium is 0.7 to $1.0 \mathrm{Os} \mathrm{kg}^{-1}$ (Robaina et al., 1990). Explants cultivated in a high concentration of glycerol did not regenerate (Table 2), but they maintained the morphogenetic capability as shown after reculture in $0.3 \mathrm{~mol} \mathrm{1}^{-1}$ glycerol (Table 3). The results in Table 3 suggest that explants accumulated glycerol and when they were recultivated to a non-inhibitory culture medium $\left(0.3 \mathrm{~mol}^{-1}\right)$ the morphogenetic effect of glycerol was even higher. Consequently, the inhibiting 

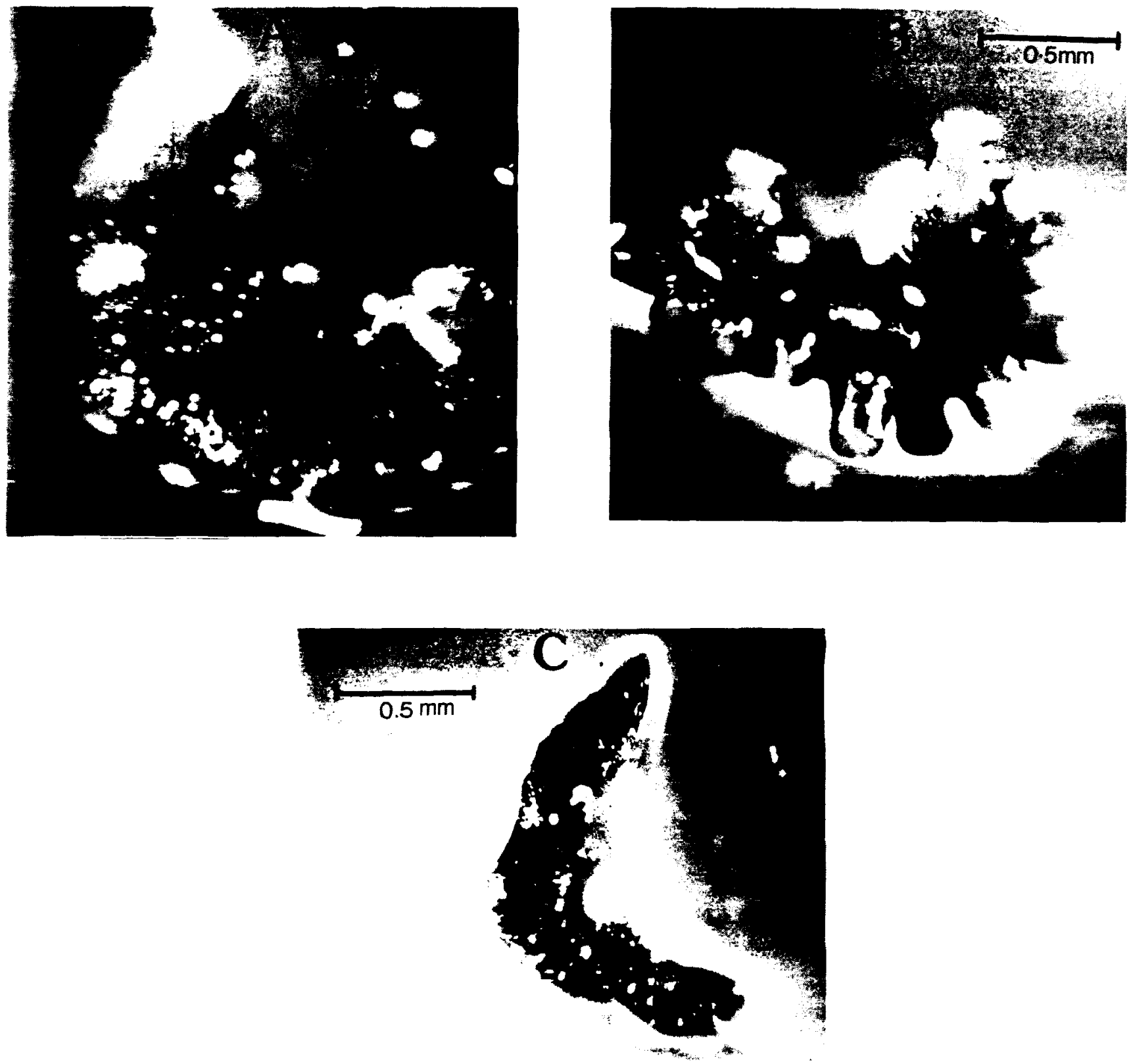

Fig. 2. Explant morphoiogy after 20 days of culture in PES70 $+0.3 \mathrm{~mol} !^{-1}$ glycerol $+15 \mathrm{~g} 1^{-}$: $:$gar (A), PES70+0.3 mol rivcerol $+8 \mathrm{~g} \mid{ }^{\prime}$ agar $(\mathrm{B})$. and PES $+8 \mathrm{~g} \mathrm{l}^{-1} \operatorname{agar}(\mathrm{C})$.

effect of high concentrations of glycerol is due to the high osmolality of the culture medium (Table 1) rather than an inhibitory effect of glycerol. Mannose. glucose or galactose did not promote growth or morphogenesis of the explants. Galactose and mannose appear to be somewhat inhibitory for tud formation (Table 5). Since the osmolality of these culture media ranged from 0.8 to $1.0 \mathrm{Os} \mathrm{kg}^{-1}$. an osmotic effect of the mentioned carbon sources is discarded. Glucose, fructose. mannitol and otrer carbon sources were not effective in Ecklonia ir. :he light (Lawlor et al.. 
1988). The absence of a co-factor or inhibition of enzymes required for carbon metabolism were suggested by Lawlor et al. (1989) as a cause of the failure of several carbon sources, including glycerol and mannitol, to induce growth in the dark. The results obtained with glycerol (Fig. $1 \&$ 2, Tables $2 \& 5$ ) clearly show that carbon metabolism is not inhibited in Grateloupia doryphora. Perhaps $G$. doryphora prefers glycerol as a carbon source or the enhancement of the viscosity of the culture medium promoted by glycerol contributes not only to facilitate the diffusion of ions, as suggested by Fries (1985), but also glycerol uptake. Carbon metabolism in $G$. doryphora harbours interesting problems and requires further research.

The main effect of glycerol in solid medium appears to be as a morphogenic inductor, since the higher the glycerol content of the culture medium the stronger the morphogenic response of the explants after transfer (Table 3). Moreover, bud cultures change from longitudinal growth to morphogenesis when they are cultivated in a glycerol-containing medium (Table 4). Glycerol compounds are involved in osmoadaptation in seaweeds (Kauss, 1967; Reed et al., 1980; Reed, 1985; Macler, 1988) and intracellular osmotic compounds have been implicated in shoot induction in higher plant tissue cultures (Brown et al., 1979). Still, the fact that galactose and mannose are not so effective as glycerol obscures the implication of glycerol compounds in the morphogenetic effect of glycerol.

The agar concentration of the culture medium affects morphogenesis in higher plants (Brown et al., 1979; Debergh 1983). In G. doryphora, bud regeneration is also reduced by high agar concentration in the culture medium (Robaina et al., 1990). The data in Table 2 show that an increase in the concentration of agar reduced the morphogenetic effect of glycerol. The capacity of glycerol to promote growth does not seem to be reduced as the explants reached a similar size in all media containing glycerol, regardless of their agar concentration. The increase in explants developing into compact cell masses when the agar concentration is increased, points to the implication of agar not only in the induction of filamentous callus-like cell masses, but also in the disorganization of the whole explant (Fig. 2a).

Glycerol did not substitute for photosynthetic activity as explants cultivated in the dark did not grow or renegerate. Other effects of the light could be involved, since light controls the metabolism of some carbon compounds in algae (Lüning, 1981), and light has been implicated in the regulation of floridoside synthesis in Gelidium (Macler, 1986).

In conclusion, glycerol is an effective carbon source for Grateloupia dorvphora tissue culture, promoting growth and morphogenesis. The effects of glycerol are influenced by the osmolality of the culture medium (glycerol content), agar concentration and light.

\section{Acknowledgements}

We are grateful to Dr Nieves Gonzalez for assistance with the taxonomy and collection of the algae. Grants from the Spanish Ministerio de Education y Ciencia to R.R.R. and from the Fundacion Universitaria de Las Palmas to P.G. are gratefully acknowledged.

\section{References}

Brown DC, Leung DW, Thorpe TA (1979) Osmotic requirement for shoot formation in tobacco callus. Physiol. PI. 46: 36-41.

Debergh PC (1983) Effects of agar brand and concentration on the tissue culture medium. Physiol. PI. 59: 270-276.

Fries L (1973) Requirements for organic substances in seaweeds. Bot. Mar. 16: 19-31.

Fries L (1984) Induction of plantlets in axenically cultivated rhizoids of Fucus spiralis. Can. J. Bot. 62: 1616-1620.

Garcia-Reina G. Luque A (1988) Analysis of the organogenetic potential of calli of three Canary Island $\mathrm{LycO}$ persicon esculenrum and races. Plant Cell Tissue Organ Culture 12: 279-283.

Kauss H (1967) Metabolism of isofloridoside galactopyranosyl (1-1) glycerol and osmotic balance in the fresh water alga Ochromonas malhamensis. Nature 214: 1129-1130.

Lawlor HJ, McComb JA, Borowitzka MA (1988) The development of filamentous and callus-like growth in axenic tissue cultures of Ecklonia radiata (Phaeophyta). In $\mathrm{T}$. 
Stadler, J. Mollion, M-C. Verdus. Y. Karamanos. H. Morvan and D. Christiaen (eds). Algal Biotechnology. Elsevier Applied Science. London: 139-150.

Lawlor HJ, McComb JA, Borowitzka MA (1989) Tissue culture of Ecklonia radiata (Phaeophyceae, Laminariaies): effects on growth of light, organic carbon source and vitamins. J. appl. Phycol. 1: 105-112.

Lobban CS, Harrison PJ, Duncan MJ (1985) The Physiological Ecology of the Seaweeds. Cambridge University Press, Cambridge: 114-119.

Lüning K (1981) Light. In CS Lobban. VJ Wynne (eds). The Biology of Seaweeds. Blackwell. Oxford: 326-355.

Macler BA (1986) Regulation of carbon flow by nitrogen and light in the red alga, Gelidium coulteri. Pl. Physiol. 82: 136-141.

Macler BA (1988). Salinity effects on photosynthesis, carbon allocation, and nitrogen assimilation in the red alga, Geiidum coulteri. Pl. Physiol. 88: 690-694.
Provasoli L (1968) Media and prospects for the cultivation of marine algae. In A. Watanabe. A Hattori (eds), Cultures and Collections of Algae. Japanese Society Plant Physiology, Hakone 63-75.

Reed RH (1985) Osmoacclimatisation in Bangia atropurpurea (Rhodophyta, Bangiales): the osmotic role of floridoside. Br. phycol. J. 20: 211-218.

Reed RH, Collins JC, Russell G (1980) Effects of salinity upon the galactosyl-glycerol content and concentration of the marine red algae Porphyra purpurea. J. exp. Bot. 31: 1539-1554.

Robaina RR, Garcia-Reina G, Luque A (1990) The effects of the physical characteristics of the culture medium on the development of red seaweeds in tissue culture. Proc. Int. Seaweed Symp. 13 (In press).

Saga N, Motomura T, Sakai Y (1982) Induction of callus from the marine brown alga Dictrosiphon foeniculaceus. $\mathrm{Pl}$. Cell Physiol. 23: 727-730. 